\title{
FARMACIJOS SPECIALISTO IR GYDYTOJO BENDRAVIMAS IR BENDRADARBIAVIMAS VISUOMENĖS VAISTINĖSE DIRBANČIŲ FARMACIJOS SPECIALISTŲ POŽIŪRIU
}

\author{
Iveta Bitkauskaitė, Aurimas Galkontas, Danguolė Grūnovienė \\ Kauno kolegija
}

\begin{abstract}
Raktažodžiai: gydytojas, farmacijos specialistas, komandinis darbas, tarpprofesinis bendradarbiavimas.
\end{abstract}

\begin{abstract}
Santrauka
Bendravimas, komandinis darbas ir sveikatos priežiūros specialistų komunikavimas lemia sveikatos priežiūros paslaugų saugą ir efektyvumą. Gydytojų ir farmacijos specialistų bendradarbiavimas sudaro sąlygas veiksmingai perduoti informaciją apie pacientą, greitai išspręsti vaistų terapijos problemas ir duoda teigiamus darbo rezultatus. Pacientams, sergantiems lètinèmis ligomis, skiriami ịvairūs vaistiniai preparatai, didinantys nepageidaujamų reiškinių riziką. Veiksmingai paciento priežiūrai ir sveikatai pagerinti, farmacijos specialistai turi efektyviai bendradarbiauti su gydytoju. Tyrimo tikslas - išanalizuoti X rajono farmacijos specialistų požiūrị i farmacijos specialisto ir gydytojo bendravimą ir bendradarbiavimą, siekiant efektyvaus sveikatos priežiūros paslaugų teikimo. Atlikta anoniminė anketinè apklausa. Tyrime dalyvavo 134 farmacijos specialistai. Tyrimo rezultatai atskleide, jog gydytojai ir farmacijos specialistai efektyviai nebendradarbiauja. Pagrindinès bendravimo ir bendradarbiavimo kliūtys yra laiko stoka, gydytojo nepasitikèjimas farmacijos specialisto kompetencija, farmacijos specialistų ir gydytojų asmeninés savybès. Kone trečdalis farmacijos specialistų jaučia baimę bendrauti su gydytojais, o daugiau kaip pusè respondentų atsaké, jog gydytojai nerodo jokios tarpprofesinio bendradarbiavimo iniciatyvos.
\end{abstract}

\section{Ivadas}

Gydytojų ir farmacijos specialistų bendradarbiavimas bei komunikavimas teikia galimybę veiksmingai perduoti informaciją apie pacientą, greitai išspręsti vaistų terapijos problemas ir duoda teigiamus darbo rezultatus [1]. Pacientams, sergantiems lètinèmis ligomis, skiriami ịvairūs vaistiniai preparatai, todèl didejja nepageidaujamų reiškinių rizika. Veiksmingai paciento priežiūrai ir sveikatai pagerinti, farmacijos specialistai turi efektyviai bendradarbiauti su gydytojais [2].

Lietuvoje yra vienintelis teisès aktas, apibrěžiantis gydytojų ir farmacijos specialistų bendradarbiavimą, - tai Geros vaistiniu praktikos nuostatai, kuriuose nurodyta, jog „Vertindamas gydymo vaistais rezultatus, vaistininkas turi bendradarbiauti su gydytojais ir pacientų organizacijomis" [3]. Vaistinès, kurios vadovaujasi Geros vaistiniu praktikos nuostatais, remiasi farmacinès rūpybos principais, aprèpiančiais atsakingą gydymą vaistais, siekiant pagerinti paciento gyvenimo kokybę.

S. Balkyte (2016) ištyrè, kad Lietuvoje efektyvus farmacijos specialisto ir gydytojo bendradarbiavimas nèra išvystytas [4]. A. Romeikienè (2016), tyrusi farmacijos specialistų, dirbančių daugiau nei 15 metų visuomenès vaistinése, bendradarbiavimo su gydytojais patirtị, atskleide, kad dažniausiai farmacijos specialistai ir gydytojai bendrauja tik pastebejję netikslumų: neteisingai išrašytas receptas, neaiški vaistų dozè ir pan. Kita priežastis, dèl kurios bendrauja sveikatos priežiūros specialistai, yra konsultavimas dèl tam tikrų vaistų, prekių, ar naujų teisès aktų išaiškinimo. Dažniausiai gydytojas ir farmacijos specialistas efektyviai nebendradarbiauja dèl laiko trūkumo, ar kai gydytojas nepasitiki farmacijos specialisto kompetencija [5].

Tarpprofesinis bendradarbiavimas yra bendravimo ir sprendimu prièmimo procesas, siekiant bendro tikslo. Pagrindinis bendradarbiavimo medicinoje tikslas yra kuo geriau patenkinti pacientų gerovès bei sveikatos poreikius. Gydytojų ir farmacijos specialistų bendradarbiavimas pacientų gerovei - esminè diegiamos farmacinès rūpybos sąlyga [6]. Šiuolaikinę sveikatos priežiūrą teikia tarpdisciplininès sveikatos priežiūros komandos, kurios, noredamos užtikrinti veiksmingą ir saugią paciento priežiūrą, remiasi efektyviu komandiniu darbu ir bendravimu. Tam tikras procentas klaidų, dèl 
kurių padaroma žala paciento sveikatai, dažniausiai priskiriamas sveikatos priežiūros specialistų komunikavimo klaidoms. Bendrieji psichikos modeliai, abipusè pagarba ir pasitikejjimas bei uždaro tipo bendravimas mokslinèje literatūroje apibrèžiamas kaip pagrindinès sąlygos veiksmingoms sveikatos priežiūros komandoms, nors sveikatos priežiūros aplinkoje nemažai iššūkių [7]. Siekiant permainų, tobulinant farmacijos specialisto - gydytojo bendradarbiavimą, būtina farmacijos studijų planus pritaikyti prie sparčiai besikeičiančių farmacijos specialisto funkcijų. Pavyzdžiui, Didžiosios Britanijos, Nyderlandų ir Belgijos pastarujų metų farmacijos studentai mokosi farmakoterapines problemas analizuoti ir spręsti kartu su medicinos studijų studentais (būsimais gydytojais, slaugos specialistais ir kt.). Taikant ši metodą, pradedamas ankstyvas gydytojo - vaistininko santykiu formavimasis, skatinamas klinikinès farmakologijos, farmakoterapijos disciplinų gilesnis supratimas [8]. C. Brown ir kolegų (2006) atlikto tyrimo rezultatai parode, kad pacientai apie vaistų vartojimo klaidas dažniau praneša farmacijos specialistui, nei gydytojui. Farmacijos specialistas išklauso pacientų problemas, susijusias su netinkamu vaistu poveikiu, nepageidaujamomis reakcijomis. Norint išvengti šių problemų, farmacijos specialistai turi informuoti gydytojus, kad būtų užtikrintas pacientų gydymo saugumas [9].

Tyrimo tikslas - atskleisti farmacijos specialisto ir gydytojo bendravimą ir bendradarbiavimą $\mathrm{X}$ rajono visuomenès vaistinèse dirbančių farmacijos specialistų požiūriu.

\section{Tyrimo medžiaga ir metodai}

Mokslinès literatūros ir reglamentuojančių teisès aktų analizè, kurios tikslas - išsiaiškinti farmacijos specialisto ir gydytojo bendravimą ir tarpprofesinị bendradarbiavimą. Empirinio tyrimo metodas - anoniminè anketinė apklausa, kurios tikslas išsiaiškinti farmacijos spe-

cialisto ir gydytojo bendravimą ir bendradarbiavimą visuomenès vaistinėse dirbančių farmacijos specialistų požiūriu. Imtis apskaičiuota remiantis Valstybinès vaistų kontrolès tarnybos prie Lietuvos Respublikos sveikatos apsaugos ministerijos duomenimis (2020), parodžiusiais, kad tiriamajame rajone dirba 166 farmacijos specialistai. Naudotasi imties dydžio skaičiuokle Raosoft sample size calculator. Norint gauti reprezentatyvius tyrimo duomenis, kurie atspindètų generalinę aibę, reikia apklausti 117 farmacijos specialistų (esant 5 proc. paklaidai). Išdalinta 117 anoniminių anketų raštu, 106 grįžo tinkamai užpildytos. Kitiems farmacijos specialistams buvo išsiųsta nuoroda užpildyti anketą internetu, gautos 28 anketos. Iš viso grịžo 134 analizei tinkamos anketos, todèl galima teigti, jog gauti rezultatai atspindi tiriamujų populiaciją. Duomenų analize atlikta Microsoft Office programinio paketo 2013 metų versijos Word ir Excel programomis.

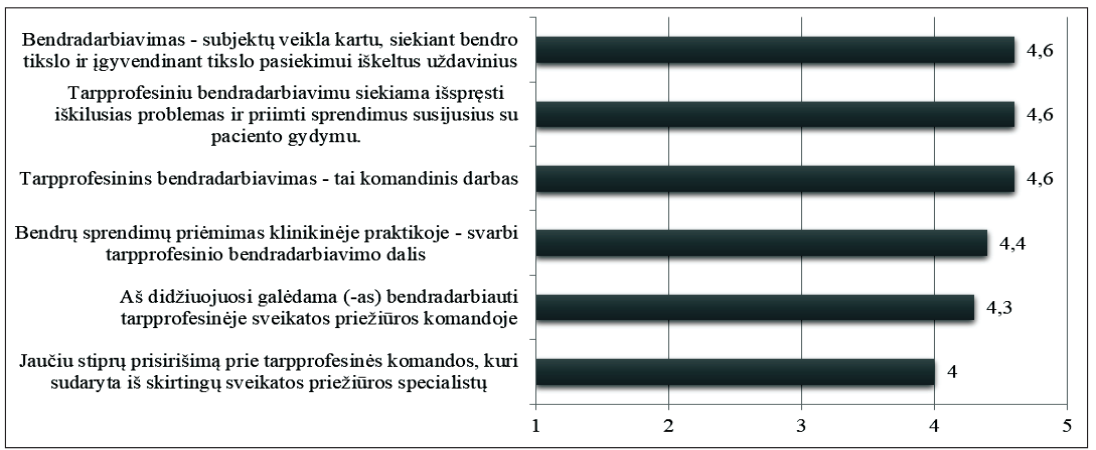

1 pav. Farmacijos specialistų nuomoné apie profesinị bendradarbiavimą ir bendravimą $(\mathrm{N}=134)$

Pastaba. Pateiktas Likerto skales vidurkis. Kuo jis didesnis, tuo labiau respondentai sutinka su pateiktu teiginiu.

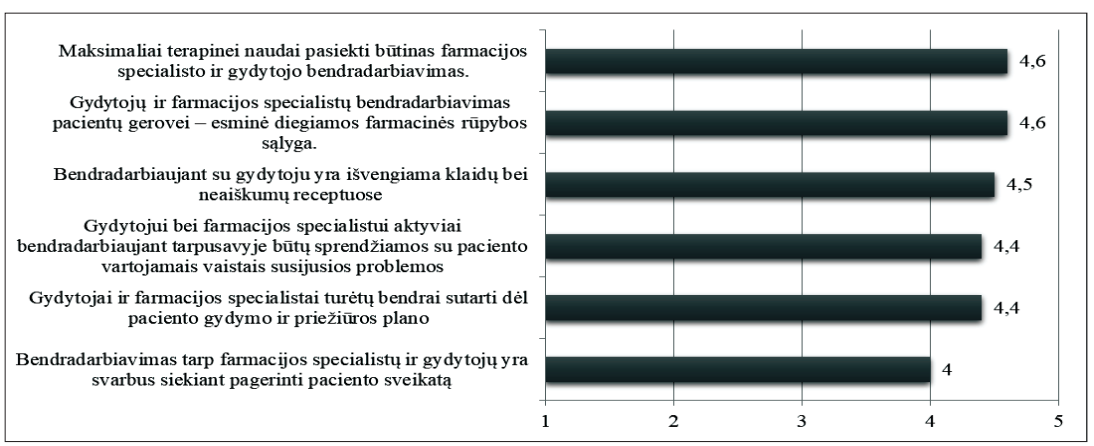

2 pav. Farmacijos specialistų bendradarbiavimo su gydytojais svarba $(\mathrm{N}=134)$

Pastaba. Pateiktas Likerto skalès vidurkis. Kuo jis didesnis, tuo respondentai labiau sutinka su pateiktu teiginiu.

3 pav. Priežastys, lemiančios farmacijos specialistų ir gydytojų bendradarbiavimą $(\mathrm{N}=134)$

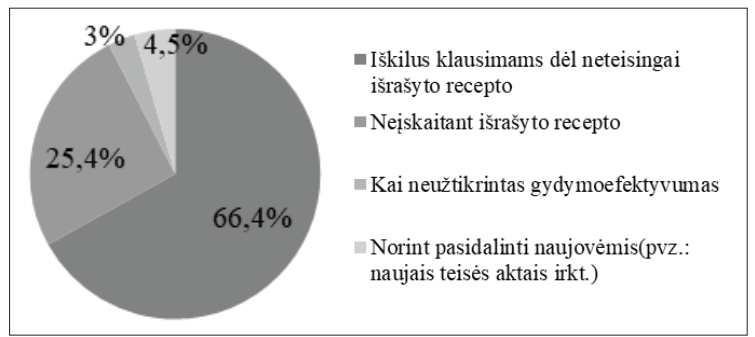




\section{Tyrimo rezultatai}

Tyrime dalyvavo 134 farmacijos specialistai, priklausantys įvairioms demografinèms grupèms. Didžiąą tyrimo dalyvių dalị sudare moterys. Teirautasi respondentų nuomonès apie tarpprofesinį bendradarbiavimą.

Gauti ịverčiai (1 pav.) atskleide, kad didžioji dalis respondentų $(4,6)$ pritare teiginiui, kad tarpprofesiniu bendradarbiavimu galima išspręsti problemas ir priimti sprendimus, susijusius su vaistinès paciento gydymu, kad skirtingų sveikatos priežiūros specialistų bendradarbiavimas - subjektų veikla kartu, siekiant bendro tikslo ir įgyvendinant tikslo pasiekimui iškeltus uždavinius. Respondentai $(4,4)$ sutiko, kad bendrų sprendimų prièmimas klinikinèje prak-

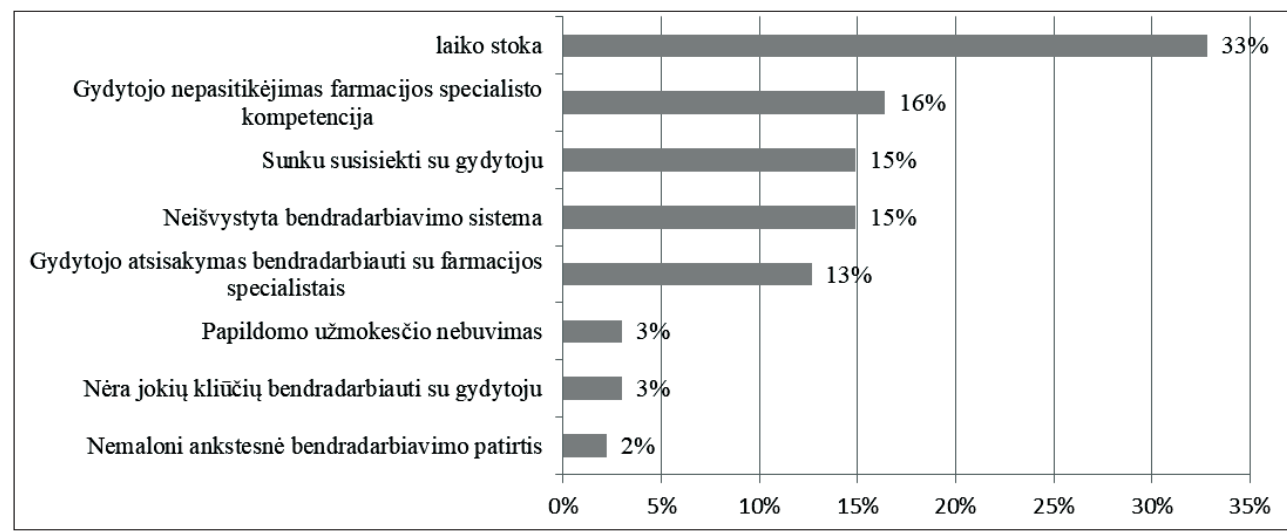

4 pav. Dažniausios farmacijos specialistų ir gydytojų bendradarbiavimo kliūtys $(\mathrm{N}=134)$

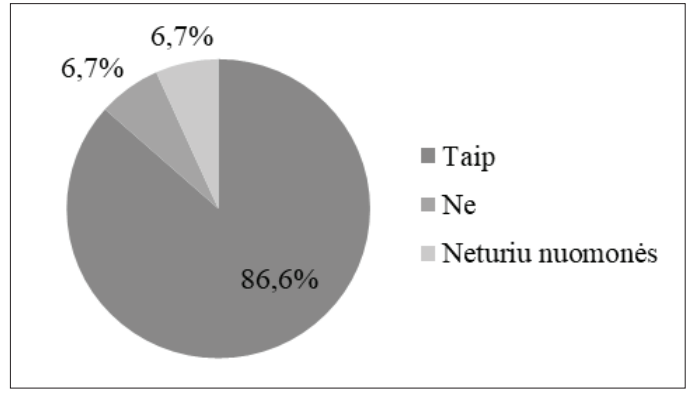

5 pav. Respondentų nuomonè, ar bendradarbiavimas su gydytojais padètų spręsti pacientų problemas $(\mathrm{N}=134)$

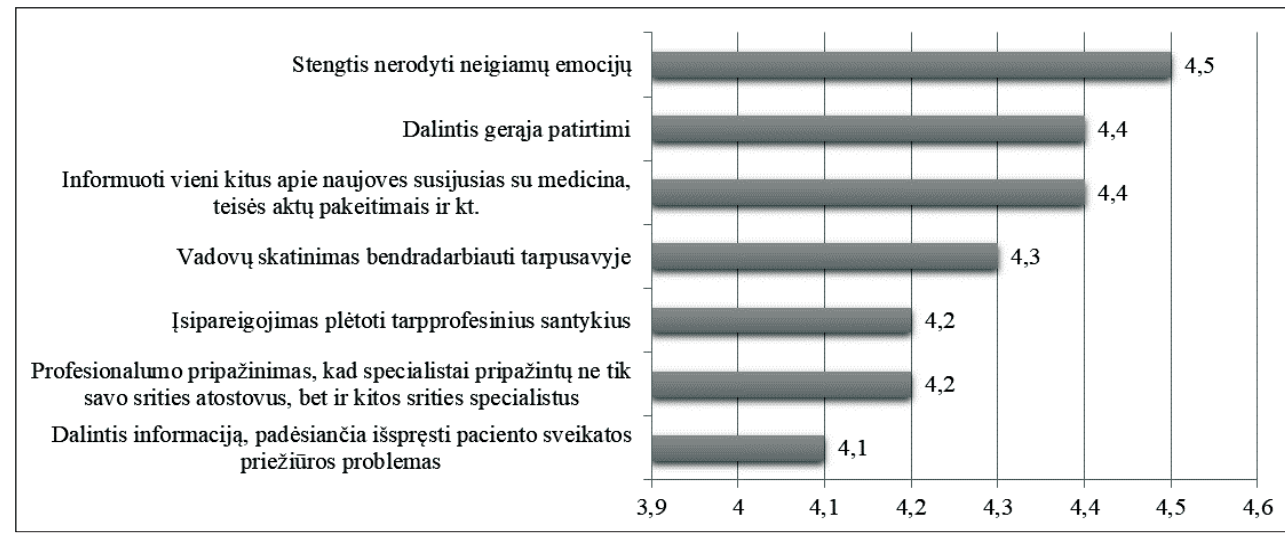

6 pav. Farmacijos specialistų ir gydytojų glaudesnị bendradarbiavimą lemiančios priežastys $(\mathrm{N}=134)$ Pastaba. Pateiktas Likerto skales vidurkis. Kuo jis didesnis, tuo respondentai labiau sutinka su pateiktu teiginiu. tikoje - svarbi tarpprofesinio bendradarbiavimo dalis, kad didžiuojasi $(4,3)$, galèdami bendradarbiauti tarpprofesineje sveikatos priežiūros komandoje. Taip pat šie teiginiai farmacijos specialistams daugiau priimtini, nei nepriimtini. Gauti rezultatai parodè, kad tarpprofesinị bendradarbiavimą respondentai suvokia kaip komandini darbą, kuriuo siekiama spręsti problemas ir priimti sprendimus.

Tyrimo metu aiškinantis farmacijos specialistu bendradarbiavimo su gydytojais svarbą, didžioji dalis $(4,5)$ respondentu visiškai pritarè, kad bendradarbiaujant su gydytoju išvengiama klaidų bei neaiškumų receptuose. Dauguma respondentų $(4,6)$ mano, kad gydytoju ir farmacijos specialistu bendradarbiavimas pacientu gerovei - esminé diegiamos farmacinès rūpybos sąlyga ir kad su paciento vartojamais vaistais susijusios problemos būtų sprendžiamos specialistams aktyviai bendradarbiaujant tarpusavyje. Šiam teiginiui tiriamieji iš esmès pritarè $(4,4)$. Galime teigti, kad farmacijos specialistu ir gydytojų bendradarbiavimas yra svarbus $(4,6)$, siekiant gauti didžiausią terapinę naudą ir pagerinti paciento sveikatą (2 pav.).

Tyrimo metu norèta išsiaiškinti respondentų nuomonę, kokios pagrindinès priežastys lemia far- 
macijos specialistų ir gydytojų bendradarbiavimą. Gauti duomenys atskleidè, kad didžioji dalis respondentų $(66,4 \%)$ su gydytojais bendradarbiauja kilus klausimų dèl neteisingai išrašyto recepto, ketvirtadalio $(25,4 \%)$ teigimu, kai neįskaito gydytojo recepto, maža dalis $(4,5 \%)$ nurode, kad su gydytoju bendraujama, norint pasidalinti naujovèmis (pvz.: naujų teisès aktų taikymas, konsultavimasis dèl paciento sveikatos pagerinimo ir kt.) ir 3,0 proc., kai norima užtikrinti gydymo efektyvumą (3 pav.).

Tyrimo metu buvo siekiama nustatyti, kokios dažniausios kliūtys lemia neefektyvų farmacijos specialistų ir gydytojų bendradarbiavimą. Trečdalio respondentų $(33,0 \%)$ nuomone, pagrindinè neefektyvaus bendradarbiavimo su gydytojais priežastis - laiko stoka. Mažiau nei po penktadalị respondentų teigè, kad gydytojai nepasitiki farmacijos specialistų kompetencija, atsisako su jais bendradarbiauti. Farmacijos specialistams sunku susisiekti su gydytojais, nes neišvystyta bendradarbiavimo sistema. Labai nedidele tiriamujų dalis $(3,0 \%)$ nepatyrè bendradarbiavimo su gydytoju kliūčių. Tyrimas atskleidẻ dažniausias farmacijos specialistų ir gydytojų neefektyvaus bendradarbiavimo priežastis: laiko stoka, gydytojų nepasitikèjimas farmacijos specialistų kompetencija, gydytojų atsisakymas bendradarbiauti su farmacijos specialistais (4 pav.). Šios priežastys atliepia mokslineje literatūroje nurodomas bendradarbiavimo kliūtis, trukdančias farmacijos specialistų ir gydytojų efektyviam komandiniam darbui.

Aiškinantis, ar bendradarbiavimas su gydytojais, respondentų nuomone, padètų spręsti pacientų problemas, nustatyta, kad didžioji dalis $(86,6 \%)$ respondentų mano, jog glaudesnis farmacijos specialistų ir gydytojų bendradarbiavimas padètų spręsti pacientų problemas, susijusias su per dideliu vaistinių preparatų vartojimu. Mažumos nuomone, tai neturètų reikšmès (5 pav.).

Respondentams buvo pateikti teiginiai, skirti išsiaiškinti priežastis, kurios galètų lemti glaudesnị sveikatos priežiūros specialistų bendradarbiavimą. Tyrimo rezultatai parodè, jog dauguma respondentų $(4,4)$ sutinka, kad dalijimasis geraja patirtimi, informavimas apie naujoves, pagerintų ịvairių sveikatos priežiūros specialistų bendradarbiavimą. Didžioji dalis $(4,5)$ mano, kad neigiamų emocijų nerodymas, profesionalumo (kitos srities specialistų) pripažinimas, tarpprofesinių santykių plètojimas skatintų farmacijos specialistų ir gydytojų bendravimą ir užtikrintų paciento gydymo efektyvumą, o vadovų skatinimas bendradarbiauti tarpusavyje garantuotų geresnius santykius. Galima daryti prielaidą, kad pateikti teiginiai farmacijos specialistams buvo daugiau priimtini, nei nepriimtini (6 pav.).

\section{Išvados}

1. Gauti tyrimo rezultatai parode, kad norint pasiekti kokybiškų rezultatų užtikrinant paciento sveikatos būklę, farmacijos specialistas ir gydytojas privalo bendradarbiauti tarpusavyje. Šių specialistų bendradarbiavimas užtikrintų gydymo efektyvumą, padètų išvengti problemų, susijusių su vaistų vartojimu. Tai ne tik pagerintų sveikatos priežiūros specialistų tarpusavio santykius, bet ir motyvuotų pacientą prisidèti prie savo sveikatos gerinimo. Gydytojo, farmacijos specialisto ir paciento bendradarbiavimas - neatsiejama grandinè, kuri gali padèti išvengti netinkamo vaistų vartojimo, užtikrinti paciento gerovę.

2. Nustatyta, jog gydytojai su farmacijos specialistais efektyviai nebendradarbiauja. Atskleistos pagrindinès bendravimo ir bendradarbiavimo kliūtys: laiko stoka, gydytojo nepasitikejjimas farmacijos specialisto kompetencija, farmacijos specialistų ir gydytojų asmeninès savybès. Beveik trečdalis farmacijos specialistų jaučia baimę bendrauti su gydytoju, daugiau kaip pusė respondentų atsakè, jog gydytojai nerodo tarpprofesinio bendradarbiavimo iniciatyvos.

\section{Literatūra}

1. Cromer J, Hojjat R, Peker S, Aprile J. Fostering the pharmacistphysician relationship. Am J Heal Pharm 2009;66(2):118-9.

https://doi.org/10.2146/ajhp080237

2. Katoue MG, Awad AI, Al-Jarallah A, Al-Ozairi E, Schwinghammer TL. Medical and pharmacy students' attitudes towards physician-pharmacist collaboration in Kuwait. Pharm Pract (Granada) 2017;15(3):1-10.

https://doi.org/10.18549/PharmPract.2017.03.1029

3. Dèl geros vaistinių praktikos nuostatų patvirtinimo. Lietuvos Respublikos sveikatos apsaugos ministro 2007 m. birželio 15 d. įsakymas Nr. V-494 (aktuali redakcija 2020-07-01) Valstybès žinios 2007; 68(2690).

https://e-seimas.lrs.lt/portal/legalAct/lt/TAD/TAIS.300204/asr

4. Balkytė S. Bendrosios praktikos gydytojų bendradarbiavimo su visuomenès vaistinèse dirbančiais farmacijos specialistais patirtis: kokybinis tyrimas. LSMU 2016:49.

5. Romeikienė A. Farmacijos specialistų, dirbančių daugiau nei 15 metų visuomenès vasitinėse, bendradarbiavimo su gydytojais patirties vertinimas: kokybinis tyrimas. LSMU 2016:51.

6. Palšauskas G, Daukšienė J, Kizevičienė E, Gaurylienė R. Panevėžio miesto gydytojų požiūris į farmacijos specialisto ir gydytojo bendradarbiavimą. Sveikatos mokslai, 2015;25(5):176-9. https://doi.org/10.5200/sm-hs.2015.108

7. Weller J, Boyd M, Cumin D. Teams, tribes and patient safety: overcoming barriers to effective teamwork in healthcare. Postgrad Med J 2014;90(1061):149-54.

https://doi.org/10.1136/postgradmedj-2012-131168

8. Kubilienė L, Radžiūnas R, Naudžiūnas A. ir kt. Farmacinès 
paslaugos klinikiniai konsultavimo pagrindai. LSMU Leidybos namai, 2014:364.

9. Brown CA, Bailey JH, Lee J, Garrett PK, Rudman WJ. The pharmacist-physician relationship in the detection of ambulatory medication errors. Am J Med Sci 2006;331(1):22-4.

https://doi.org/10.1097/00000441-200601000-00007

\section{COMMUNICATION AND COOPERATION BETWEEN A PHARMACIST AND A PHYSICIAN, FROM THE POINT OF VIEW OF PHARMACISTS WORKING IN A PUBLIC PHARMACY}

\section{Bitkauskaitė, A. Galkontas, D. Grūnovienė}

Key words: physician, pharmacist, team work, interprofessional collaboration.

\section{Summary}

Communication, teamwork and collaboration among health care professionals is important for the safe and effective delivery of health care. Collaboration between physicians and pharmacists allows for effective communication of patient information, rapid resolution of drug therapy problems, and positive outcomes. Patients with chronic illnesses are prescribed a variety of medications and are therefore more likely to experience side effects. For effective patient care, pharmacists must work effectively with the physician to improve patient health.

The study sought to analyse the attitudes of pharmacists in city $\mathrm{X}$ towards the communication and collaboration between a pharmacist and a physician in order to provide effective health care services.

The results of the study revealed that doctors do not cooperate effectively with pharmacists, as well as the main obstacles to communication and cooperation: lack of time, distrust of the pharmacist, personal characteristics of pharmacists and doctors, as almost a third of pharmacists mentioned fear of communicating with doctor. More than half of pharmacists responded that the doctor did not show any initiative for interprofessional collaboration.

Correspondence to: aurimas.galkontas@go.kauko.lt

Gauta 2020-10-15 